\title{
Effect of Controlled Hemorrhage on Tissue and Serum Cefazolin Clearance
}

\author{
Thomas E. Brothers, M.D., ${ }^{* 1}$ Thomas W. Wakefield, M.D., ${ }^{*}$ Dennis R. Schaberg, M.D., $†$ \\ Carl L. Pierson, Ph.D., Linda M. Graham, M.D., ${ }^{*, 2}$ and James C. Stanley, M.D.* \\ *Section of Vascular Surgery, Department of Surgery; + Division of Infectious Disease, Department of Medicine; \\ and $\ddagger$ Department of Pathology; University of Michigan Medical School, Ann Arbor, Michigan 48109
}

Submitted for publication August 8, 1990

\begin{abstract}
Effects of blood loss on tissue and serum antibiotic levels were investigated in $30 \mathrm{New}$ Zealand white rabbits. Studies were conducted over a 3.5-hr period after intravenous administration of cefazolin, $30 \mathrm{mg} / \mathrm{kg}$, in control animals (Groups I and IV, $n=5$ each) and animals having $50 \%$ (Groups II and V, $n=5$ each) or $100 \%$ (Groups III and VI, $n=5$ each) of their blood volume removed and replaced with either Ringer's solution (Groups I, II, and III) or rabbit whole blood (Groups IV, $V$, and VI) sufficient to maintain central venous pressures at baseline levels. Periodic samples of retroperitoneal fat, iliac artery, and serum were assayed for cefazolin concentration by disc diffusion. Decreased tissue antibiotic levels were observed in animals undergoing $100 \%$ blood replacement (Groups III and VI) compared to controls (Groups I and IV) in both fat $(P \leqslant 0.01)$ and artery $(P \leqslant 0.01)$ at $90 \mathrm{~min}$. Decreased antibiotic serum half-life accompanying hemorrhage existed when comparing Group II to I $(P \leqslant 0.05)$, Group III to I $(P \leqslant 0.01)$, and Group IV to $V(P \leqslant 0.01)$. The increased antibiotic clearance related to blood loss in this study justifies reassessment of intraoperative dosing intervals. More frequent dosing may be required to maintain stable tissue and serum antibiotic levels during substantial operative hemorrhage. 1991 Academic Preas, Inc.
\end{abstract}

\section{INTRODUCTION}

Certain surgical infections are catastrophic, and considerable efforts are directed at their avoidance. Among these are prosthetic vascular graft infections, estimated to occur in 1 to $6 \%$ of arterial reconstructive procedures. The use of prophylactic antibiotics in these patients has

\footnotetext{
1 To whom correspondence should be addressed at University of Michigan Hospital-2210 THCC, 1500 East Medical Center Drive, Ann Arbor, MI 48109.

${ }^{2}$ Current address: Veterans Administration Hospital, Cleveland, $\mathrm{OH}$.
}

gained widespread favor and appears justified in reducing the risk of infection [1-5]. However, to be effective agents for prophylaxis, antibiotics must be present in sufficient concentration at potential sites of contamination throughout the operation, and such may not always be the case during vascular reconstructions.

Most contemporary perioperative antibiotic dosing regimens are derived from pharmacokinetic studies utilizing either a single dose or constant infusion of antibiotics [6]. Surprisingly little data exist on antibiotic clearance during shifts in body fluid associated with periods of major blood loss and fluid replacement as might occur during vascular surgery. It is hypothesized that significant decreases in tissue antibiotic concentration may accompany blood loss and compromise the intended prophylaxis, as well as fail to counteract the increased susceptibility to infection associated with hemorrhagic shock $[7,8]$. The present investigation was undertaken to better define the effect of blood loss on antibiotic clearance. In particular, tissue and serum cefazolin levels were assessed in rabbits undergoing controlled hemorrhage and resuscitation.

\section{METHODS}

Thirty adult New Zealand white rabbits weighing 1.9 to $3.7 \mathrm{~kg}$ were anesthetized with ketamine $(40 \mathrm{mg} / \mathrm{kg} \mathrm{im})$ and xylazine $(2.5 \mathrm{mg} / \mathrm{kg} \mathrm{im})$, with supplemental ketamine $(10 \mathrm{mg} / \mathrm{kg} \mathrm{im})$ administered as needed. All animals were mechanically ventilated through a tracheotomy. External jugular veins and common carotid arteries were cannulated with 20 -gauge catheters. The jugular catheters were used for central venous pressure measurements as well as infusion of antibiotics and fluids. The carotid catheters were used for systemic arterial blood pressure measurements as well as phlebotomy. Retroperitoneal fat and iliac arteries were exposed through midline abdominal incisions.

Thirty minutes following rapid intravenous bolus infusion of cefazolin (Ancef, SmithKline \& French, Philadelphia, PA), $30 \mathrm{mg} / \mathrm{kg}$, the rabbits were divided into six 


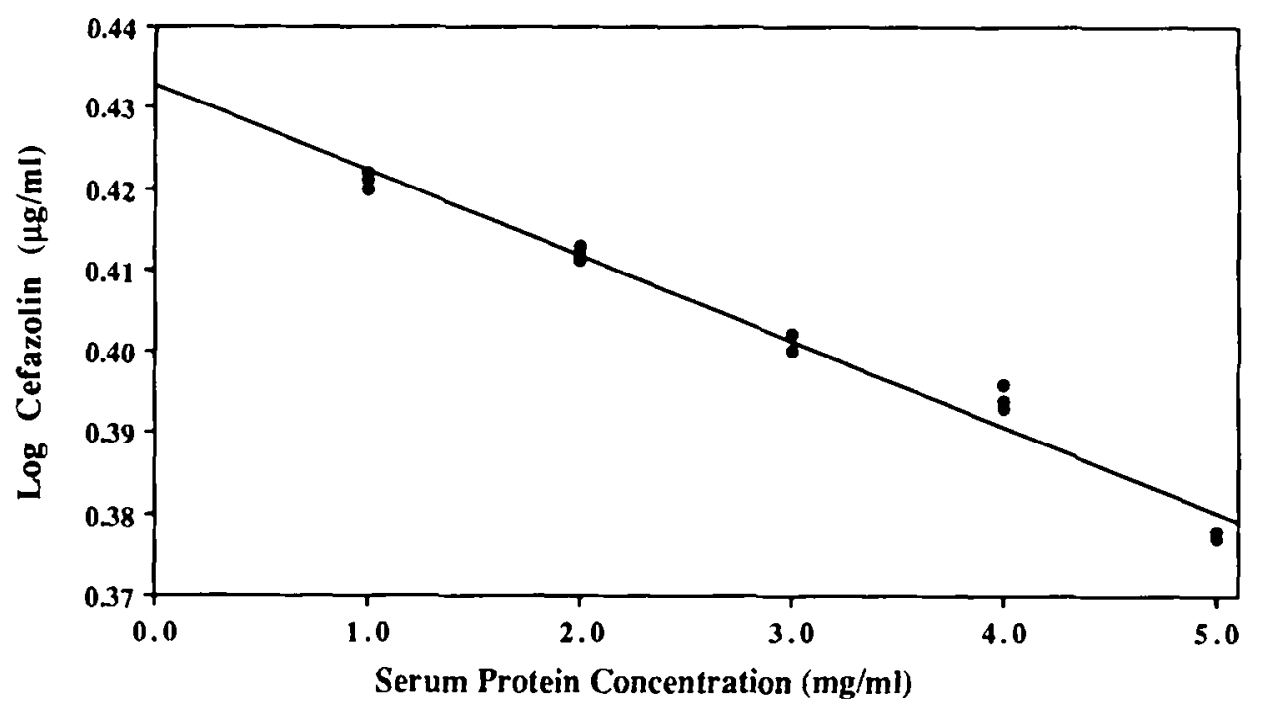

FIG. 1. Cefazolin concentration, measured by disc diffusion, as a function of serum protein concentration. Linear regression $y=0.435$ $-0.0555 x, r=0.99, P<0.001$.

study groups: controls (Groups I and IV, $n=5$ each), animals bled $50 \%$ of their total blood volume (Groups II and $\mathrm{V}, n=5$ each), and animals bled $100 \%$ of their total blood volume (Groups III and VI, $n=5$ each). Total blood volume was calculated to be $6 \%$ of body weight. Central venous pressure was maintained at baseline levels in this investigation by infusing either warmed Ringer's lactate solution (Groups I, II, and III) or citrated pooled rabbit whole blood (Groups IV, V, and VI) as the replacement fluid during bleeding or as the maintenance fluid in control animals. Retroperitoneal adipose tissue and arterial blood were sampled hourly throughout the study. Five-millimeter-long sections of left external iliac arteries were removed at $1.5 \mathrm{hr}$ and similar sections of right external iliac arteries were removed at $3.5 \mathrm{hr}$. In neither circumstance was arterial continuity reestablished. Animal care complied with standards in The Guide for the Care and Use of Laboratory Animals (NIH Publication 85-23, revised 1985).

Antibiotic assays were performed in triplicate using disc diffusion methods with $4 \mathrm{hr}$ of incubation at $37^{\circ} \mathrm{C}$. Weighed tissue specimens were homogenized in disposable chambers (Fisher Scientific, New York, NY) for 10 min in $100 \mu \mathrm{l}$ of sterile water. Blood was allowed to stand at $25^{\circ} \mathrm{C}$ for $1 \mathrm{hr}$ and centrifuged at $2000 \mathrm{~g}$ to obtain serum. Twenty-microliter aliquots of tissue homogenate or serum were added to $6.35-\mathrm{mm}$ paper discs (Difco, Detroit, MI) using disposable pipet tips and placed on

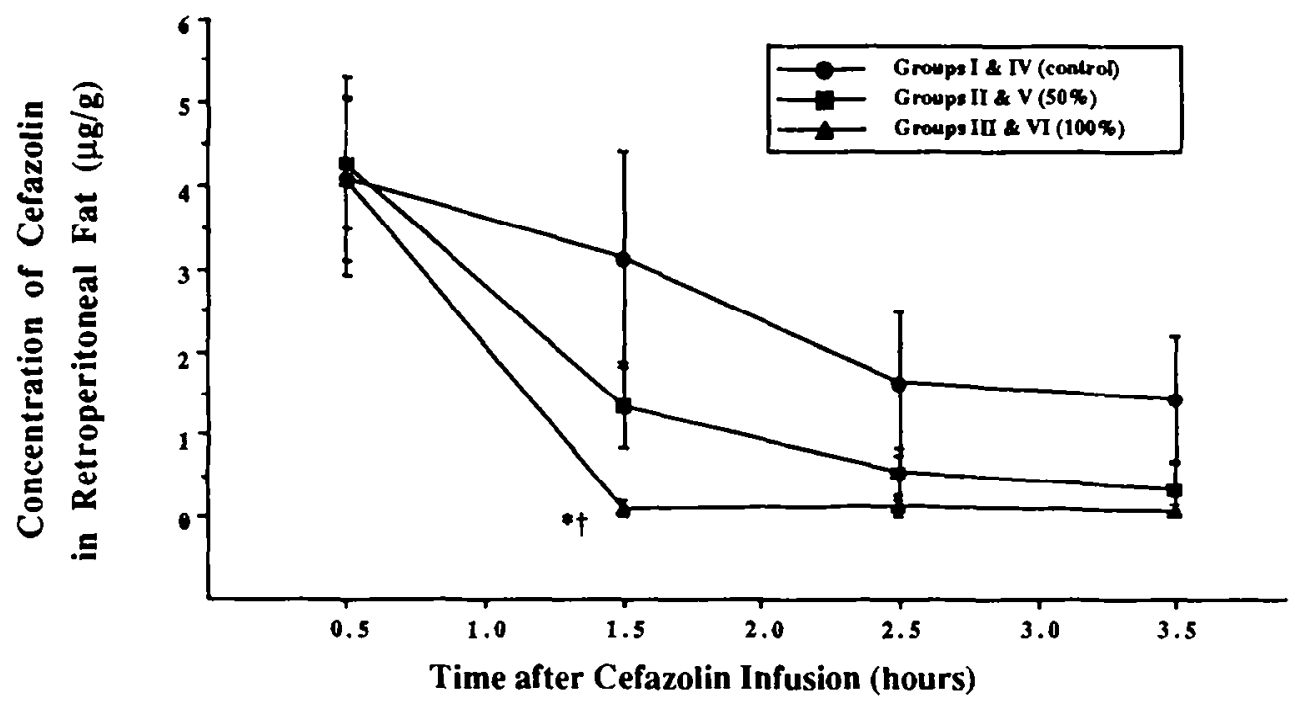

FIG. 2. Effect of blood loss on cefazolin concentration in retroperitoneal fat samples. ${ }^{*} P<0.01$ vs controls (Groups I and IV); $\uparrow P<0.05$ vs subjects with $50 \%$ blood loss (Groups II and V). Error bars represent \pm standard error of the mean. 


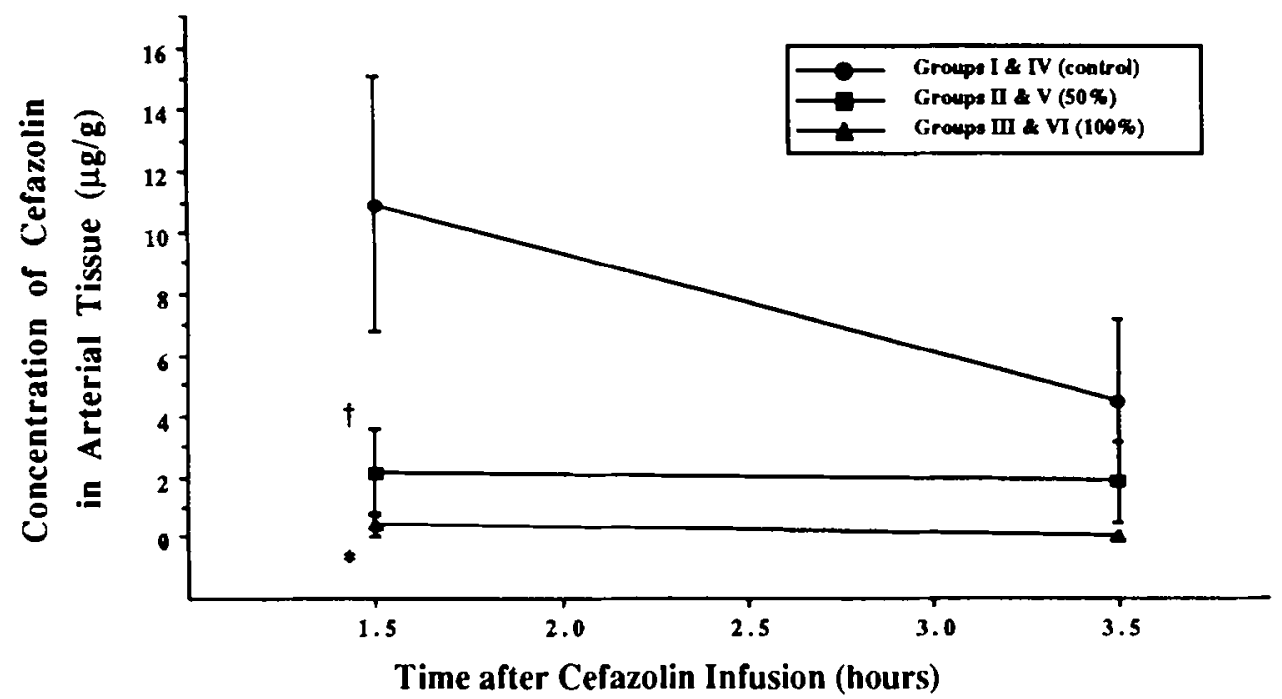

FIG. 3. Effect of blood loss on cefazolin concentration in iliac artery samples. ${ }^{*} P<0.01$ vs controls (Groups I and IV); $+P<0.05$ vs subjects with $50 \%$ blood loss (Groups II and V). Error bars represent \pm standard error of the mean.

plates seeded with $B$. subtilis in antibiotic medium 5 (Difco, Detroit, MI).

Standards were prepared with pooled rabbit serum. To define minimum assayable tissue concentrations, cefazolin was added to predetermined quantities of untreated fat or artery and assayed as previously described. Additional standards of identical antibiotic concentrations were also prepared in different dilutions of serum to assess effects of protein concentration on assay results. Serum protein levels were measured before and after resuscitation from hemorrhage.

Tissue and serum pharmacokinetic data were analyzed using an unpaired $t$ test. $\chi^{2}$ one-way ANOVA, and linear regression analysis were utilized in assessing other data as appropriate.

\section{RESULTS}

Reliable minimum assayable cefazolin tissue concentrations were $1.0 \mu \mathrm{g} / \mathrm{g}$ of fat and $5.0 \mu \mathrm{g} / \mathrm{g}$ of arterial tissue. These tissue concentration differences may have been related to the high protein binding $(86 \%)$ of cefazolin, being less in adipose than arterial tissue. Serum cefazolin concentration determined by disc diffusion correlated inversely with serum protein concentration (Fig. 1). Therefore, standardization of serum cefazolin

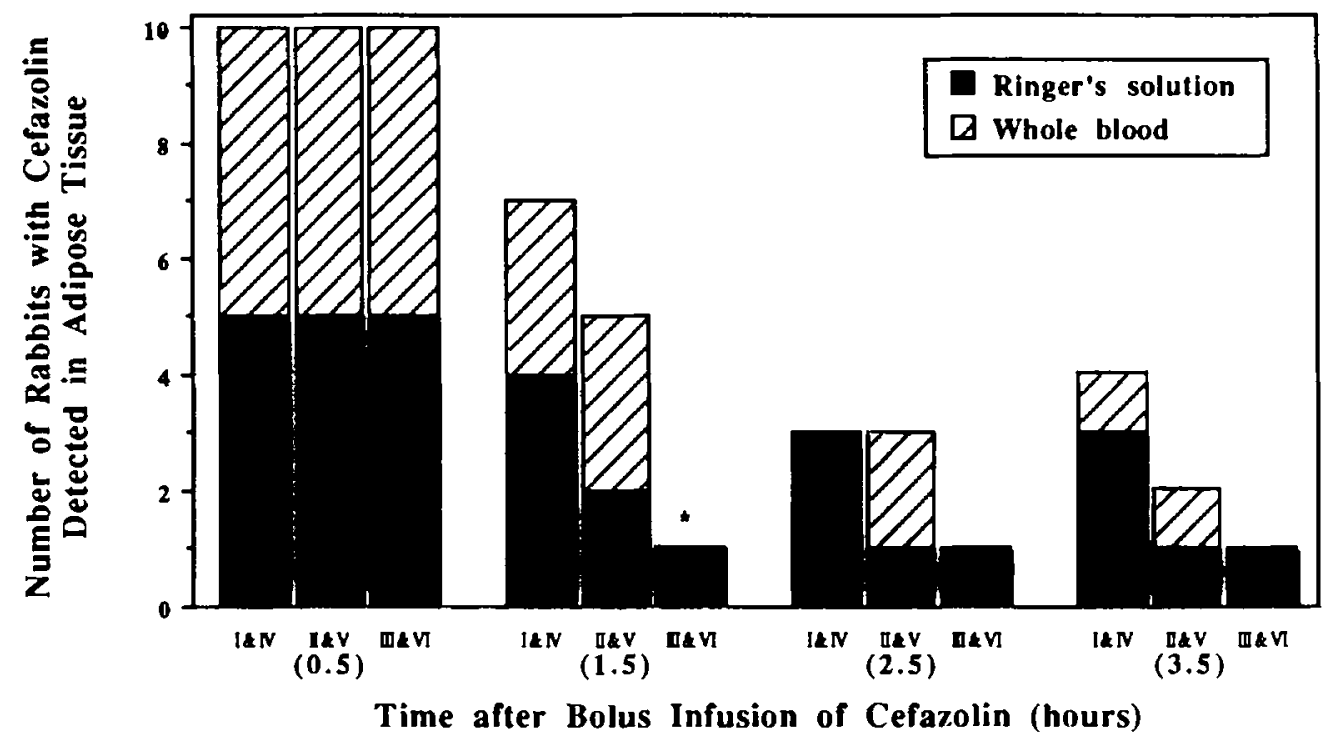

FIG. 4. Effect of blood loss on the number of animals with cefazolin detected in retroperitoneal fat samples. ${ }^{*} P<0.01$ v8 controls (Groups I and IV). 


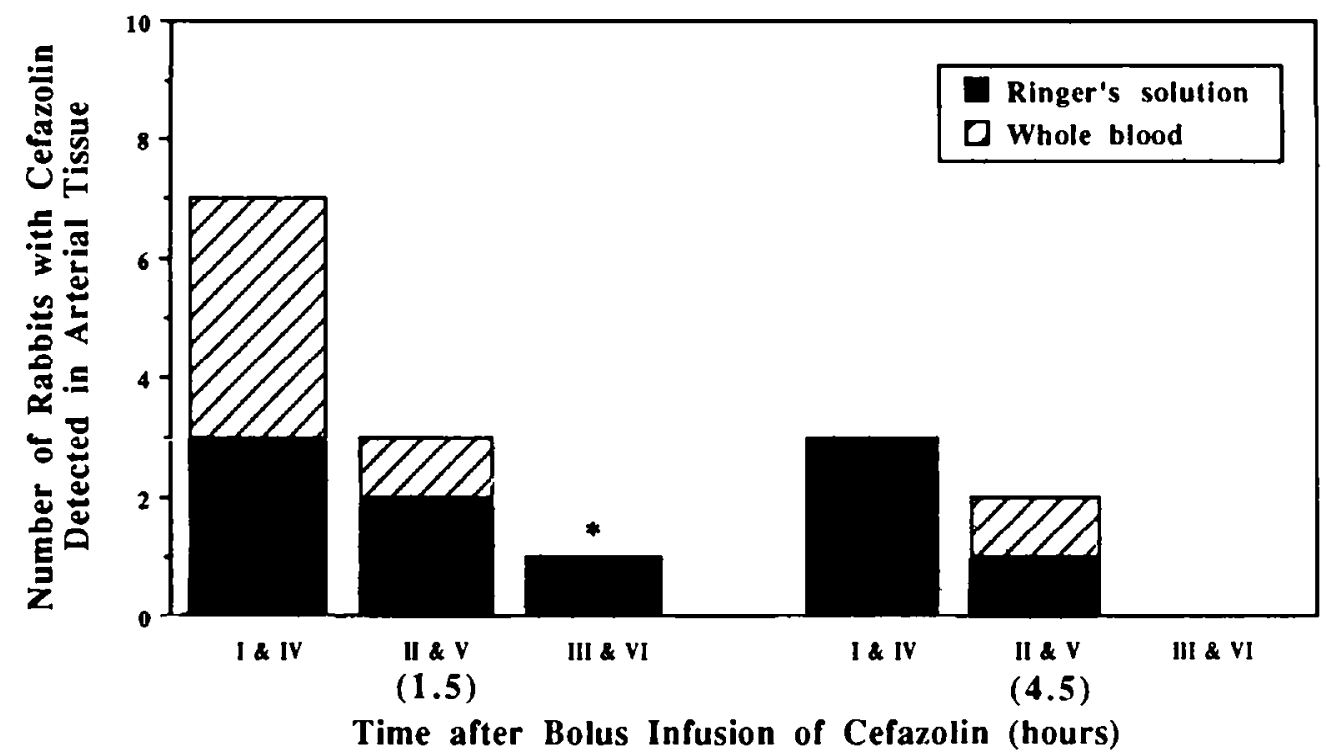
IV).

FIG. 5. Effect of blood loss on the number of animals with cefazolin detected in iliac artery samples. ${ }^{*} P<0.01$ vs controls (Groups I and

values according to measured serum protein levels was important in all half-life calculations of the antibiotic. Mean systemic arterial pressures were dissimilar between experimental groups and included Group I, 40 $\pm 12 \mathrm{~T}$ (means \pm standard deviation); Group II, $38 \pm 12$ T, Group III, $37 \pm 18$ T; Group IV, $80 \pm 14$ T; Group V, $53 \pm 16 \mathrm{~T}$; and Group VI, $56 \pm 12 \mathrm{~T}$.

Tissue data from animals resuscitated using Ringer's solution and whole blood were combined due to small individual group sample sizes. Increases in retroperitoneal fat antibiotic levels comparing controls (Groups I and IV) to rabbits undergoing complete blood volume replacement (Groups III and VI) were significant ( $P$ $\leqslant 0.01$ ) at $1.5 \mathrm{hr}$ (Fig. 2). Similar increases in arterial tissue antibiotic levels in controls (Groups I and IV) compared to animals bled $100 \%$ (Groups III and VI) were also significant $(P \leqslant 0.01)$ at $1.5 \mathrm{hr}$ (Fig. 3 ). Differences in antibiotic levels at $1.5 \mathrm{hr}$ between Groups $V$ and VI did not reach statistical significance in either arterial tissue $(2.6 \mu \mathrm{g} / \mathrm{g}$ vs $0 \mu \mathrm{g} / \mathrm{g})$ or adipose tissue $(1.6 \mu \mathrm{g} / \mathrm{g}$ vs 0 $\mu \mathrm{g} / \mathrm{g}$ ). Significant differences in the number of animals with detectable antibiotic existed between these same animals (Groups I and IV compared to Groups III and VI) in both fat $\left(\chi^{2}, P \leqslant 0.01\right)$ and arterial tissue $\left(\chi^{2}, P\right.$

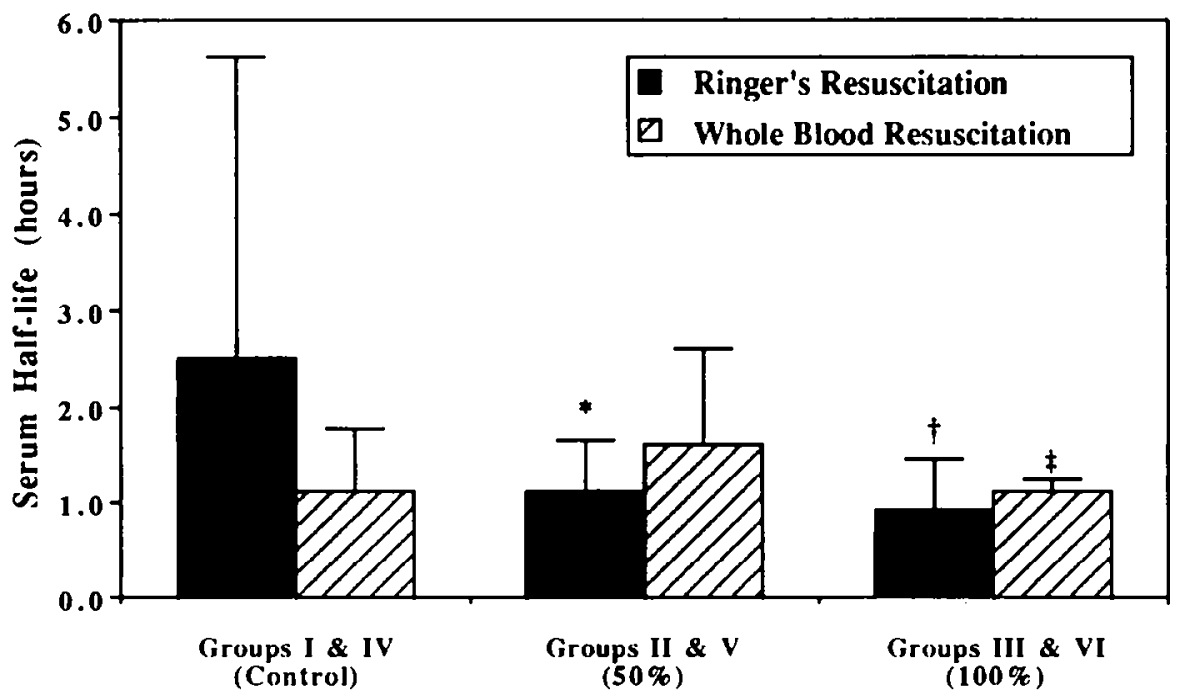

FIG. 6. Effect of blood loss and manner of resuscitation on cefazolin serum half-life. ${ }^{*} P<0.05$ vs controls (Group I); $+P<0.01$ vs controls (Group I); $\ddagger P<0.01$ vs subjects with $50 \%$ blood loss (Group V). 


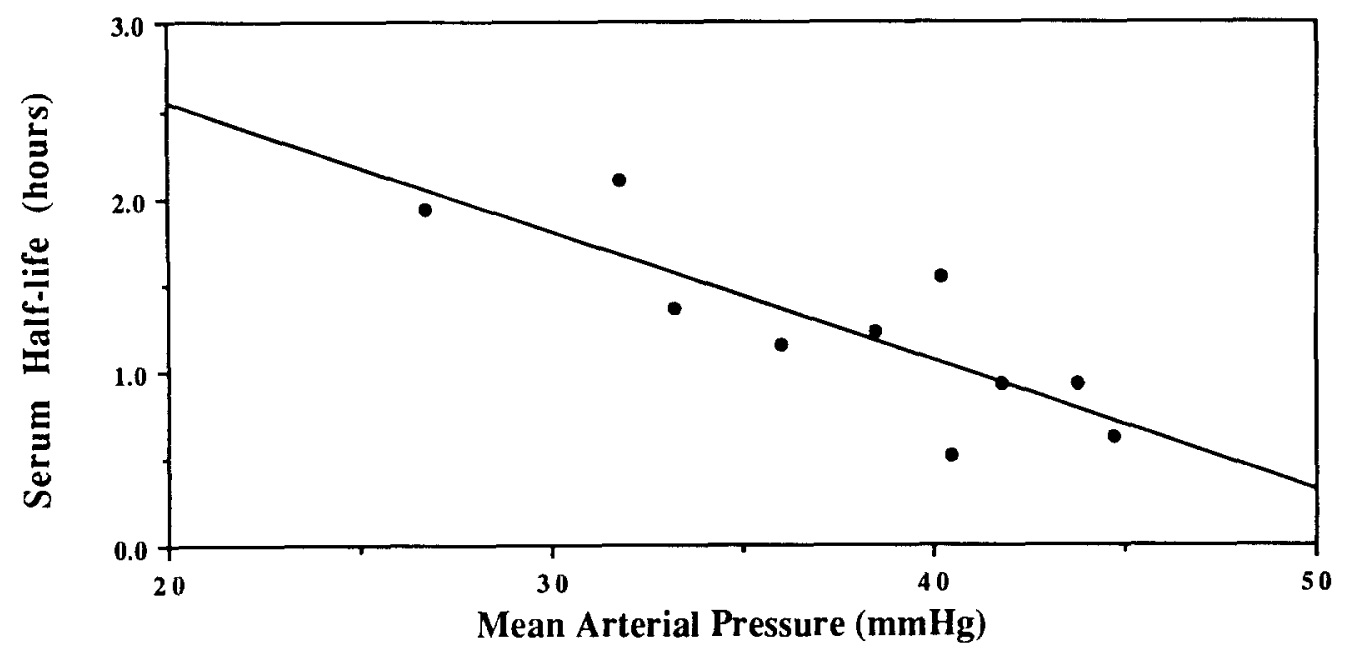

FIG. 7. Cefazolin serum half-life in animals bled and resuscitated with Ringer's solution as a function of the mean arterial pressure. Linear regression $y=4.02-0.07 x, r=0.81, P<0.005$.

$\leqslant 0.01)$ at $1.5 \mathrm{hr}$ (Figs. 4 and 5). However, no differences in fat or artery antibiotic levels occurred at later time periods.

Differences in serum half-life were observed among subjects resuscitated with Ringer's solution comparing control animals (Group I) and animals bled $100 \%$ of their blood volume (Group III, $P \leqslant 0.01$ ), as well as in comparisons of control animals (Group I) and animals bled $50 \%$ of their blood volume (Group II, $P \leqslant 0.05$ ). Differences were also observed among subjects resuscitated with whole blood, when comparing animals bled $50 \%$ (Group V) and 100\% (Group VI, $P \leqslant 0.01$ ) of their respective blood volume, but not controls (Group IV) (Fig. 6). Although not statistically significant, serum half-lives of cefazolin were different in the two control groups $(3.5 \pm 1.5 \mathrm{hr}$ in Group I and $1.4 \pm 0.6 \mathrm{hr}$ in Group IV). This difference most likely reflected the lower mean arterial blood pressure in the former group. A clear association existed between antibiotic serum half-life and tissue levels for all groups (ANOVA, $P \leqslant 0.01$ ).

It is noteworthy that persistence of detectable tissue antibiotic at $3.5 \mathrm{hr}$ in both fat $(P \leqslant 0.01)$ and artery $(P$ $\leqslant 0.05$ ) samples was inversely related to the rabbit's mean systemic arterial blood pressure, regardless of the type of resuscitation. Antibiotic serum half-life following hemorrhage and resuscitation with Ringer's was also inversely related to mean systemic arterial blood pressure $(P \leqslant 0.005)$ (Fig. 7). These data support the tenet that low mean arterial pressures are independent predictors of diminished antibiotic clearance. It is important to recognize that in this study, mean systemic arterial pressure was directly related to the degree of blood loss $(P \leqslant 0.01)$, so that the lower blood pressures associated with increased blood loss may have caused an underestimation of the increase in antibiotic clearance otherwise observed with increased blood loss.

\section{DISCUSSION}

Antibiotic prophylaxis in surgical patients is more relevant to tissue levels than serum levels. In general, tissue antibiotic levels at sites of potential contamination dictate prophylactic efficacy, although this topic continues to be debated $[9,10]$. Many techniques exist for assessing antibiotic penetration into tissues, including measurements of antibiotic accumulation in intraperitoneal perforated containers, subcutaneous fibrin clots, subcutaneous Visking chambers, lymphatic duct fluid, cutaneous forearm blisters, subcutaneously implanted umbilical tape, and homogenized tissue. Utilization of the disc diffusion bioassay of antibiotic activity in tissue homogenates, a less sensitive technique than liquid chromatography, appears adequate for studies such as the present one. In the current investigation, levels of antibiotic were reliably detected within the recommended therapeutic ranges of four to eight times minimum inhibitory cefazolin concentrations [1.0-2.0 $\mu \mathrm{g} / \mathrm{g}$ for $S$. aureus] [11]. Although the serum cefazolin concentration correlated inversely with serum protein concentration, the extent of protein binding has been shown to affect neither tissue penetration nor the efficacy of an antibiotic [12]. In the present study, significant differences in tissue antibiotic levels were detected only during the first $1.5 \mathrm{hr}$ after cefazolin administration. This $1.5-\mathrm{hr}$ time interval represents the usual half-life of cefazolin under stable hemodynamic conditions. Thus, the normal serum and tissue clearance of this antibiotic prevents detection of significant clearance differences at later periods of observation.

Perioperative use of cephalosporin antibiotics has been proven effective in prophylaxis for infection during major operations including vascular reconstructions. Satisfactory tissue and serum levels for prophylaxis in 
vascular reconstruction may often be achieved with a single preoperative dose of antibiotic $[11,13,14]$. However, perioperative antibiotic pharmacokinetics may be influenced by multiple factors relevant to clinical practice. For example, tissue and serum concentrations at the time of graft placement depend on dose timing, with ineffective levels present if antibiotic is given too early [15]. Little is known about tissue and serum pharmacokinetics in the setting of substantial blood loss and fluid resuscitation. On the other hand, serum half-life as well as volume of distribution appears increased during some vascular operations [16]. This may, in part, reflect surgical trauma and redistribution of body fluids to extravascular compartments. However, tissue and serum halflife of these antibiotics may also depend upon the amount and timing of blood loss during the surgical procedure [17]. A single prospective clinical study of 20 consecutive patients undergoing noncardiac thoracic operations attempted to address this issue [18]. In this latter study, no correlations between serum cefamandol levels and degree of blood loss or replacement were observed. However, alteration in blood pressure as a possible independent modifier of antibiotic clearance was not examined, and correction for antibiotic variation due to different serum protein levels was not made in this study.

The present laboratory investigation clearly demonstrates both tissue and serum clearance of antibiotics to be altered by hemodynamic conditions similar to those that may accompany certain major surgical procedures. Loss of more than half the total blood volume causes a significant increase in antibiotic clearance and decreases fat and arterial tissue antibiotic levels. These data suggest that more frequent dosing in the clinical setting may be necessary to maintain adequate tissue antibiotic concentration during periods of substantial operative blood loss.

\section{REFERENCES}

1. Hasselgren, P., Ivarsson, L., Risberg, B., and Seeman, T. Effects of prophylactic antibiotics in vascular surgery: A prospective randomized, double-blind study. Ann. Surg. 200: 86, 1984.

2. Kaiser, A. B., Clayson, K. R., Mulherin, J. L., et al. Antibiotic prophylaxis in vascular surgery. Ann. Surg. 188: 283, 1978.
3. Pitt, H. A., Postier, R. G., MacGowan, W. A., et al. Prophylactic antibiotics in vascular surgery: Topical, systemic, or both? Ann. Surg. 192: 356, 1980.

4. Salzmann, G. Perioperative infection prophylaxis in vascular surgery: A randomized prospective study. Thor. Cardiovasc. Surg. 31: 239, 1983.

5. Wilson, S. E., Wang, S., and Gordon, H. E. Perioperative antibiotic prophylaxis against vascular graft infection. South. Med. J. (Suppl.) 70: 68, 1977.

6. Hildebrand, J. R., Merrill, D. L., and Vernick, J. J. Defining appropriate timing of surgical antibiotic prophylaxis. Inf. Surg. 5: $444,1986$.

7. Livingston, D. H., and Malangoni, M. A. An experimental study of susceptibility to infection after hemorrhagic shock. Surg. Gynecol. Obstet. 168: 138, 1989.

8. Livingston, D. H., and Malangoni, M. A. More is better: Antibiotic management after hemorrhagic shock. Ann. Surg. 208: 451, 1988.

9. Goldmann, D. A., Hopkins, C. C., Karchmer, A. W., et al. Cephalothin prophylaxis in cardiac valve surgery. $J$. Thor. Cardiovasc. Surg. 73: 470, 1977.

10. Schentag, J. J. Clinical significance of antibiotic tissue penetration. Clin. Pharmacokin. (Suppl. 1) 16: 25, 1989.

11. Fradet, G., Brister, S., Richards, G. K., et al. Antibiotic prophylaxis in vascular surgery: Pharmacokinetic study of four commonly used cephalosporins. J. Vasc. Surg. 3: 535, 1986.

12. Bergamini, T. M., and Polk, H. C., Jr. Pharmacodynamics of antibiotic penetration of tissue and surgical prophylaxis. Surg. Gynecol. Obstet. 168: 283, 1989.

13. Chou, S., Richard, G. K., and Brown, R. A. A new approach to antibiotic therapy in colon surgery based on bioassay tissue concentrations. Can. J. Surg. 25: 527, 1982.

14. Mutch, D., Richards, G., Brown, R. A., and Mulder, D. S. Bioactive antibiotic levels in the human aorta. Surgery 92: 1068, 1982.

15. DiPiro, J. T., Vallner, J. J., Bowden, T. A., Clark, B., and Sisley, J. F. Intraoperative serum concentrations of cefazolin and cefoxitin administered preoperatively at different times. Clin. Pharm. 3: $64,1984$.

16. Guglielmo, B. J., Salazar, T. A., Rodondi, L. C., Carver, M., Goldstone, J., and Stoney, R. J. Altered pharmacokinetics of antibiotics during vascular surgery. Am J. Surg. 157: 410, 1989.

17. Alexander, D. P., and Recker, J. M. Cefoxitin disposition in colorectal surgery. Ann. Surg. 208: 162, 1988.

18. Buchman, P., Siebenmann, R., Kayser, F. H., Eijsten, A., and Geroulanos, S. Beeinflussung des Serumspiegels von Cefamandol durch einen massiven Volumenersatz. Helv. Chir. Acta. 54: $763,1987$. 